\title{
Did the Iraq War Have a Body Bag Effect?
}

\author{
Babak Bahador and Scott Walker
}

Did mounting troop casualties during the Iraq War turn the American public against the conflict? Analyzing public opinion data from over 400 public polls during the first six years of the war, this article attempts to identify whether there was a "body bag effect" in play. We create a multivariate model that tests a number of potential hypotheses including cumulative and marginal troop casualty as well as death milestone effects. We find that cumulative casualties provide a better explanation for the decline in public support than marginal casualties during the Iraq War. Contrary to the findings from the Korean and Vietnam Wars, this holds true during both periods of escalation and de-escalation.

Did news of mounting U.S. casualties from the 2003 Iraq War and subsequent insurgency play a role in turning American public opinion against the war? This paper will evaluate the relative merits of several competing explanations for what drove public support during the Iraq War. Using casualty and public opinion data from March 2003 to December 2008, the authors examine whether aggregate casualties, marginal casualties, or death count milestones provide satisfactory explanations for support of the war.

This paper is divided into five sections. The first section provides an overview of the theoretical arguments and previous research relating to the "body bag effect." It begins by describing why public opinion matters on issues of war and peace, and subsequently describes the hypothesized causal mechanism of the body bag effect.

In section two, a review of a number of hypotheses regarding how the body bag effect might work is conducted in order to understand what drove public opinion after the launch of the Iraq war. Was the relationship driven by cumulative casualties, marginal casualties, death toll milestones, a cumulative/marginal casualty mix, or does the evidence favor a null hypothesis relating to elite opinions and partisan cues?

The third section presents the casualty and public opinion data over the timeline of this study using tables and a figure. It then assesses the different hypotheses outlined in the previous section based on a visual examination of the data to identify any discernable trends.

Section four offers empirical tests for the competing hypotheses presented in section two to assess if the body bag effect, in conjunction with

BABAK BAHADOR is a Senior Lecturer in Media and Communication and Political Science at the University of Canterbury. SCOTT WALKER is a Senior Lecturer in Political Science at the University of Canterbury.

The American Review of Politics, Vol. 33, Winter, 2012-2013: 247-270

(c)2012 The American Review of Politics 
other factors outlined, shaped American public support for the war. In the final concluding section, the theoretical and practical implications of these findings are discussed.

\section{The Body Bag Effect}

\section{Public Opinion and War}

The body bag effect assumes that the death of soldiers in a war impacts the public's opinion on the war in the country where the soldiers originate, generally reducing support as deaths increase. Nearly two centuries ago, von Clausewitz identified the importance of public support for war, arguing that if a war was to be successful, "the passions that are to be kindled in war must already be inherent in the people" (von Clausewitz 1993, 101). Rousseau and Kant, likewise, placed a premium on the public's role, arguing that wars could be reduced if the decision on their engagement was up to the people, who paid the ultimate cost (von Clausewitz 1993, 27).

The importance of public opinion in politics is a subject of great contention. Much of the literature is skeptical on public opinion's independence, suggesting that its malleable nature makes it susceptible to political manipulation (Entman 2000, 2004). Furthermore, because the masses tend to follow foreign affairs sporadically and mostly during crises, it has been suggested that the public's knowledge of such matters is rough and superficial (Zaller 1992, 28). Given such shortcomings, some view the consequences of public opinion on security policy with fear. According to early political communication scholar Walter Lippman: "The unhappy truth is that the prevailing public opinion has been destructively wrong at the critical junctures. ... It has shown itself to be a dangerous master of decision when the stakes are life and death" (cited in Holsti 2002, 515). Despite these limitations, it is still difficult in practice to visualize Western democratic states beginning and sustaining a war in which the majority of their people do not share the conviction to fight (Coker 2001, 48).

\section{The Body Bag Effect}

The body bag effect hypothesizes that the public's passion for war (to use von Clausewitz's characterization) declines as military deaths increase, due to the changing cost-benefit calculation of the engagement amongst ever increasing portions of the population. The most blatant alleged case of this effect occurred during the Vietnam War, when news of U.S. casualties, along with televised images of death and destruction, were widely blamed for turning the American public against the war, forcing the hand of politicians towards withdrawal (Hallin 1989, 3). Since Vietnam, according to 
Lawrence Freedman, "it has almost been taken for granted that public opinion in Western countries, and in particular the United States, is fragile and easily turned" (2000, 337).

Bill Clinton, perhaps with the 1993 Somalia debacle fresh on his mind, appeared to be extremely concerned with a potential body bag effect when he decided on how military intervention in Kosovo would proceed. On the eve of the intervention, he went on national television and stated, "I do not intend to put ground troops in Kosovo to fight a war" (White House 1999). From a military perspective, this statement appeared naïve, as it revealed information that could put the U.S. at a disadvantage by allowing the enemy to prepare for the remaining choices. Politically, however, the loss of American life could not be sustained over this particular conflict (Livingston 2000, 377). This concern was further demonstrated by the decisions to fly fighter jets at 15,000 feet, placing them out of anti-aircraft firing range (Daalder and O’Hanlon 2000, 94).

Research based on individual-level data has found that other intervening variable besides casualties are also important for public support, including the perceived "rightness" of the war, the level of progress, and the chance of success. Furthermore, findings show that although the public does not always have accurate knowledge of wartime events, it nonetheless does shift its attitudes in rational ways (Gelpi et al. 2005; Gelpi 2010). These studies build on existing research that show variations in public support to be best explained by the principal policy objective of the war (Jentleson 1992). The public is more likely to tolerate casualties when the United States is using force to restrain an aggressive state (a defensive objective), and less likely to support the use of force when its objective is to influence internal political change in target countries (an offensive objective). In short, the public is more likely to be supportive when the U.S. is trying to restrain rather than remake governments.

While the principle of the body bag effect is relatively straightforward, questions remain regarding how it functions. The next section will introduce some competing hypotheses about wartime casualties and public opinion in the context of the Iraq War.

\section{Competing Hypotheses Related to the Body Bag Effect}

\section{The Cumulative Effect Hypothesis}

John Mueller's seminal book, War, Presidents and Public Opinion, was the first to examine in depth the relationship between casualties and public opinion during wartime. Mueller argued that the log of cumulative casualties was the best determinant of the likely level of public support for war. 
According to his findings, public opinion as a whole is highly sensitive to early casualties; less sensitive to additional casualties; and again sensitive when large losses, such as tens of thousands, are recorded at later stages of a conflict $(1973,62)$.

According to Mueller, this pattern can be explained by looking at the entire public as consisting of a series of subgroups, with factions that hold similar views changing their support for a war based on criteria relevant to their particular group. In early stages, support drops amongst subgroups with "considerable misgivings" about the war as evidence of casualties mounts. These "soft" groups may consist of people who only supported the war to "rally around the flag" but who were perhaps against the war in principle (Zaller and Chu 2000, 61-63). After this initial drop, the part of the public that is still supportive often becomes hardened and accustomed to news of casualties, and support for the war stabilizes. In the latter stages, however, subgroups that had always supported the war begin to lose confidence as the costs begin to clearly outweigh the benefits of the engagement. Once hardened supporters are lost, it becomes increasingly difficult for governments to sustain a war effort.

Most typically, the cumulative casualty hypothesis contains an assumption that the public uses some sort of rational expectations process when evaluating policy success (Berinsky 2007). Under this framework, individuals view higher numbers of casualties as a sign that the war is getting worse for their side, and reduce their support accordingly.

Thus, in line with Mueller:

Hypothesis 1: The higher the number of total casualties, the lower the support for the war.

\section{The Marginal Effect Hypothesis}

While Mueller's model is a classic approach for examining the wartime casualty-opinion nexus, it has been challenged by Gartner and Segura, who argue that marginal casualty numbers (what they term "temporally proximate costs") are more important than cumulative numbers in determining the direction of public opinion - especially when casualties are rising (1998, 278). The authors argue that by examining marginal casualties, several shortcomings with Mueller's cumulative casualty model can be overcome. First, the concept of cumulative casualties is problematic because it is not distinguishable from the variable of time, which can by itself erode support due to war weariness and the end of the short-term boost from the "rally around the flag" effect. The authors argue that marginal casualties are not 
linked to time and should, therefore, be able to account for the subtle impacts of changing casualty rates and other events on opinion.

Second, Gartner and Segura claim that marginal casualties have the advantage of potentially accounting for events that may increase support for the war effort, such as declining casualty rates or other external events. These subtleties would be lost if measured solely by cumulative casualties, especially over a long period. Thus, while Mueller's research suggests that major events in a war make no difference to public opinion, Gartner and Segura find that events can either increase or decrease support. Therefore, in this study, both cumulative and marginal casualty numbers are examined to determine which is a more accurate indicator of public opinion fluctuation.

Thus, consistent with Gartner and Segura:

Hypothesis 2: Increases (decreases) in monthly casualties will lead to decreases (increases) in approval for the war.

\section{The Significant Marginal Effect Hypothesis}

It is also possible that the public may become insensitive to small monthly changes in casualties, particularly in an extended conflict over a number of years. In such a situation, opinion may respond more acutely to large marginal changes on a month-to-month basis. This seems intuitive, as it is likely that public and media attention decline over time unless something extraordinary occurs. News is, after all, about what is new.

Thus, we suggest a variant of the hypothesis above:

Hypothesis 2a: Significant (>50\%) increases (decreases) in monthly casualty averages lead to corresponding decreases (increases) in public support for the war.

\section{The Milestone Hypothesis}

If wartime events are key drivers of support for the war, as Gartner and Segura argue, then it is possible that body count thresholds also matter. As casualties reach new milestones (e.g., 500, 1,000, 2,000, 3,000, or 4,000 battle deaths), the public may interpret each new milestone as further evidence that the country's war effort has sunk to a new low. Whether the public includes such milestones in their calculations of how well the war will go over the long term, or whether they view these new body count thresholds merely as reasons to feel pessimistic for the immediate future cannot be ascertained in a study that looks at aggregate measures of public opinion. But one would expect that if the media put enough focus on these 
major milestones, the public would in one way or another assess the future of the war in a negative way.

Thus,

Hypothesis 3: Support will be lower following months when total casualties reach significant milestones.

\section{The War Duration Hypothesis}

Gartner and Segura argue that when examining the impact of casualties on the level of public support for the war, one must explicitly account for the duration of the war. The authors thus include the number of days since the onset of the war as an independent variable. By controlling for the role of time in this way, the authors argue that it is possible to isolate the effects of the casualty variables $(1998,287)$.

Thus,

Hypothesis 4: The greater the duration of the conflict, the lower the level of support for the war.

\section{Gartner and Segura's Marginal/Cumulative Mix Hypothesis}

In their analysis of both the Korean and Vietnam conflicts, Gartner and Segura (1998) create a model that attempts to reconcile the cumulative vs. marginal casualty debate. They theorize that "marginal casualties are a better predictor of opposition during periods of escalation or continuous fighting, but cumulative casualties are more likely to serve that purpose during periods of de-escalation" (Gartner and Segura 1998, 286). The reason for this trend is that during times of escalation, the public is sensitive to changes in casualties, but during times of de-escalation or non-continuous fighting, people are unlikely to shift their positions merely due to fluctuations in marginal casualties. For instance, a decline in marginal casualty rates is unlikely to change the minds of those opposed to involvement in the war due to the high overall costs.

Gartner and Segura test this hypothesis by creating a data set that combines monthly casualty and public support data for both the Korean and Vietnam Wars. Pooling the data for the two wars increases the number of observations and increases the generalizability of the study. To test their hypothesis, the authors create a model that compares the rate of casualties over the previous 120 days with that of the prior 120-day period. The authors find that cumulative casualties matter more than marginal casualties for public opinion support when casualties are declining (i.e., when the 
previous 120 days records fewer casualties than the 120-day period preceding that). In times of increasing casualties, however, marginal casualties matter more than cumulative casualties as a driver of opposition to the war.

Does this same pattern hold true for the Iraq War? Although the overall magnitude of casualties was lower compared to Korea and Vietnam, the conflict exhibited a similar initial rally in public support followed by a gradual decline. As such, we test whether a similar trend was in play in Iraq.

Thus,

Hypothesis 5: Increases in marginal casualties will result in lower support for the war during periods of rising casualties; conversely, increases in cumulative casualties will lead to lower support during times of falling casualties.

\section{The Null Hypothesis}

The possibility remains that there is no systematic relationship between any of these factors (i.e., cumulative, marginal, or milestones) and public opinion. Berinsky (2009) argues that the dominant paradigm, in which changes in individual rational expectations about the prospects for success lead to changes in support, is flawed. In fact, he argues that day-to-day political events do not affect the public's perceptions of the conflict very much. In this anti-rational expectations approach, Berinsky finds that members of the public use elite positions as cues for their opinions concerning war.

If Berinsky's reasoning holds true for the Iraq War, then battle deaths are independent of public opinion, except as filtered through elite opinion in the form of partisan cues. To illustrate this point, Berinsky uses a comparison between the Iraq War and World War II. During the Iraq war, declining support among elites in the American political system led to a decline in support for the war, as partisan supporters of those who opposed the war followed the cues of opinion leaders. However, Berinsky finds that this elite split did not emerge during World War II, and therefore support did not waver despite growing casualties.

In a follow-up study, Berinsky surveyed Americans in 2005, and found that casualty information, or "the scope of the human cost of war," had little or no effect on citizens' support for the Iraq War. Instead, it was citizens' attachments to particular political leaders that was the most important factor (2009). According to Berinsky, then, elite opinions drive mass opinion rather than wartime events such as casualties.

While our methodology does not allow us to test this hypothesis at an individual level, we can nonetheless observe whether aggregate support for the war is responsive to casualties and milestones. If it is not, these findings provide additional support to Berinsky's domestic politics argument. 
Thus,

Hypothesis 6: Wartime body bag counts and milestones do not drive public support for the war.

\section{A Visual Inspection of the Relationship between Casualties and Public Support}

From the beginning of the Iraq War on March 21, 2003, until the end of 2008, over 4,000 American soldiers died in the Iraq War. Over the same time period, public support for the war declined from approximately 70 percent to 35 percent, with most of this decline occurring in the first year of the war. This section of the paper reviews the hypotheses outlined in the previous section that can be examined through a visual inspection of public support and casualty data. The public support monthly data is based on the average support for each month from 439 polls - or approximately six polls per month, on average - conducted over the timeline. These polls were conducted by the following organizations: CNN/USA/Gallup, CNN/Opinion Research Corp., ABC News/Washington Post/TNS, Newsweek/Princeton SRA, PEW Research/Council on Foreign Relations/Princeton SRA, CBS News, Fox News/Opinion Dynamics, USA Today/Gallup, Quinnipiac University, Time/SRBI, Los Angeles Times/Bloomberg, Associated Press/ IPSOS, Program on International Policy Attitudes/Knowledge Networks and University of Pennsylvania. Support is measured by the percentage of people who responded favorably to questions asking whether they support the war or not. An example is the following question asked in the CNN/USA Today Poll: "Do you favor or oppose the U.S. war in Iraq?" (2007). Casualty data are gathered from the website of Globalsecurity.org.

As mentioned earlier, Mueller's research found two trends on the relationship of casualties and public opinion support for war. First, one should expect a decline in support with early casualties from segments of the population that rallied around the flag, but had misgivings about the decision to go to war. During the 2003 Iraq war, support for the war increased by up to 20 percent in the last few months before the start of the war, presumably from those rallying around the flag once the decision to fight appeared imminent. Mueller's second finding was that after an initial drop, remaining supporters become hardened to casualties until much larger battle death numbers in the tens of thousands emerge.

In observing the data on casualties and public opinion, outlined in Figure 1 and Table 1, there is visual evidence supporting Mueller's findings. First, while support peaked at 70 percent from the start of the war until May 2003 , it declined rapidly following evidence of a growing insurgency and a 
Figure 1. Casualties and Public Opinion from the Iraq War, 2003-08

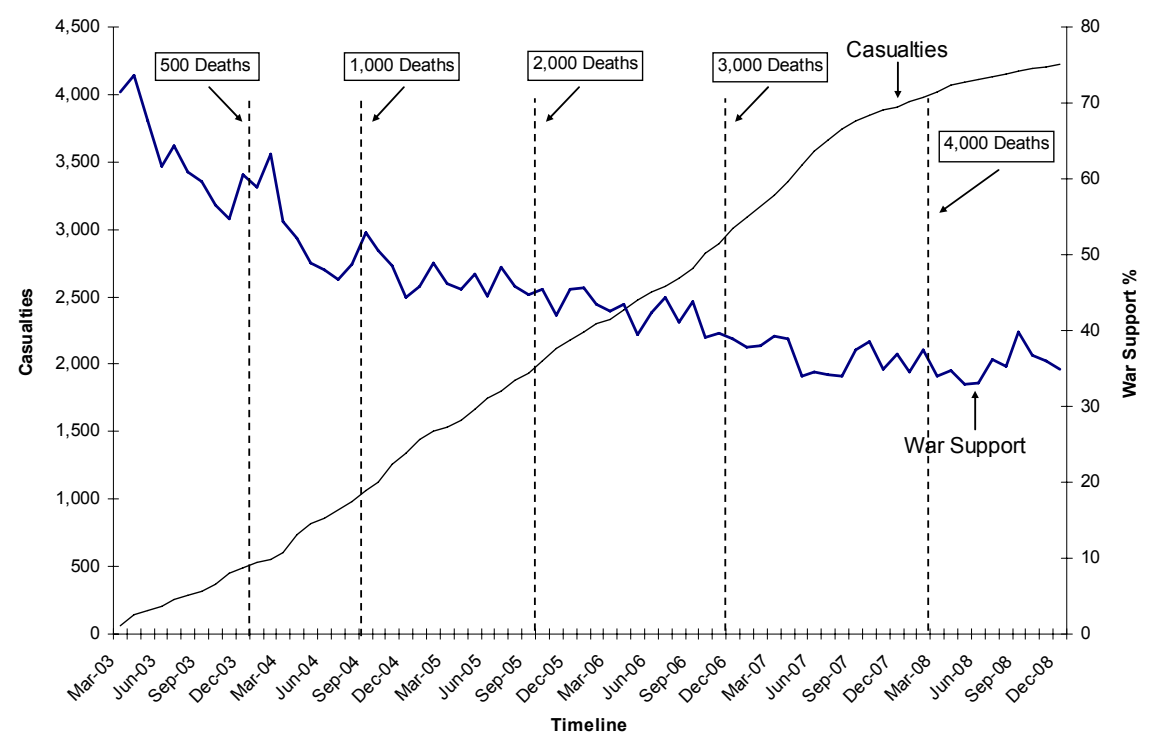

Table 1. Casualties and Public Opinion from the Iraq War, 2003-08

\begin{tabular}{lcccc}
\hline Month & $\begin{array}{c}\text { Monthly } \\
\text { Casualties }\end{array}$ & $\begin{array}{c}\text { Cumulative } \\
\text { Casualties }\end{array}$ & $\begin{array}{c}\text { Marginal } \\
\text { \% Change }\end{array}$ & $\begin{array}{c}\text { Opinion } \\
\text { \% Support }\end{array}$ \\
\hline Mar-03 & 65 & 65 & - & 72 \\
Apr-03 & 74 & 139 & 14 & 74 \\
May-03 & 37 & 176 & -50 & 68 \\
Jun-03 & 30 & 206 & -19 & 62 \\
Jul-03 & 48 & 254 & 60 & 64 \\
Aug-03 & 35 & 289 & -27 & 61 \\
Sep-03 & 31 & 320 & -11 & 60 \\
Oct-03 & 44 & 364 & 42 & 57 \\
Nov-03 & 82 & 446 & 86 & 55 \\
Dec-03 & 40 & 486 & -51 & 61 \\
Jan-04 & 47 & $\mathbf{5 3 3}$ & $\mathbf{1 8}$ & $\mathbf{5 9}$ \\
Feb-04 & 20 & 553 & -57 & 63 \\
Mar-04 & 52 & 605 & 160 & 54 \\
Apr-04 & 135 & 740 & 160 & 52 \\
May-04 & 80 & 820 & -41 & 49 \\
Jun-04 & 42 & 862 & -48 & 48 \\
Jul-04 & 54 & 916 & 29 & 47 \\
Aug-04 & 66 & 982 & 22 & 49 \\
& & & & .. . table continues
\end{tabular}


Table 1. Casualties and Public Opinion from the Iraq War, 2003-08 (continued)

\begin{tabular}{|c|c|c|c|c|}
\hline Month & $\begin{array}{c}\text { Monthly } \\
\text { Casualties }\end{array}$ & $\begin{array}{c}\text { Cumulative } \\
\text { Casualties }\end{array}$ & $\begin{array}{l}\text { Marginal } \\
\% \text { Change }\end{array}$ & $\begin{array}{l}\text { Opinion } \\
\text { \% Support }\end{array}$ \\
\hline Sep-04 & 80 & 1,062 & 21 & 53 \\
\hline Oct-04 & 64 & 1,126 & -20 & 51 \\
\hline Nov-04 & 137 & 1,263 & 114 & 49 \\
\hline Dec-04 & 72 & 1,335 & -47 & 44 \\
\hline Jan-05 & 107 & 1,442 & 49 & 46 \\
\hline Feb-05 & 58 & 1,500 & -46 & 49 \\
\hline Mar-05 & 35 & 1,535 & -40 & 46 \\
\hline Apr-05 & 52 & 1,587 & 49 & 46 \\
\hline May-05 & 80 & 1,667 & 54 & 48 \\
\hline Jun-05 & 78 & 1,745 & -3 & 45 \\
\hline Jul-05 & 54 & 1,799 & -31 & 48 \\
\hline Aug-05 & 85 & 1,884 & 57 & 46 \\
\hline Sep-05 & 49 & 1,933 & -42 & 45 \\
\hline Oct-05 & 96 & 2,029 & 96 & 45 \\
\hline Nov-05 & 84 & 2,113 & -13 & 42 \\
\hline Dec-05 & 68 & 2,181 & -19 & 46 \\
\hline Jan-06 & 62 & 2,243 & -9 & 46 \\
\hline Feb-06 & 55 & 2,298 & -11 & 44 \\
\hline Mar-06 & 31 & 2,329 & -44 & 43 \\
\hline Apr-06 & 76 & 2,405 & 145 & 43 \\
\hline May-06 & 69 & 2,474 & -9 & 40 \\
\hline Jun-06 & 61 & 2,535 & -12 & 42 \\
\hline Jul-06 & 43 & 2,578 & -30 & 44 \\
\hline Aug-06 & 65 & 2,643 & 51 & 41 \\
\hline Sep-06 & 72 & 2,715 & 11 & 44 \\
\hline Oct-06 & 106 & 2,821 & 47 & 39 \\
\hline Nov-06 & 70 & 2,891 & -34 & 40 \\
\hline Dec-06 & 112 & 3,003 & 60 & 39 \\
\hline Jan-07 & 83 & 3,086 & -26 & 38 \\
\hline Feb-07 & 81 & 3,167 & -2 & 38 \\
\hline Mar-07 & 81 & 3,248 & 0 & 39 \\
\hline Apr-07 & 104 & 3,352 & 28 & 39 \\
\hline May-07 & 126 & 3,478 & 21 & 34 \\
\hline Jun-07 & 101 & 3,579 & -20 & 35 \\
\hline Jul-07 & 80 & 3,659 & -21 & 34 \\
\hline Aug-07 & 84 & 3,743 & 5 & 34 \\
\hline Sep-07 & 66 & 3,809 & -21 & 37 \\
\hline Oct-07 & 38 & 3,847 & -42 & 39 \\
\hline Nov-07 & 37 & 3,884 & -3 & 35 \\
\hline Dec-07 & 23 & 3,907 & -38 & 37 \\
\hline Jan-08 & 40 & 3,947 & 74 & 35 \\
\hline Feb-08 & 29 & 3,976 & -28 & 37 \\
\hline
\end{tabular}


Table 1. Casualties and Public Opinion from the Iraq War, 2003-08 (continued)

\begin{tabular}{lcccc}
\hline Month & $\begin{array}{c}\text { Monthly } \\
\text { Casualties }\end{array}$ & $\begin{array}{c}\text { Cumulative } \\
\text { Casualties }\end{array}$ & $\begin{array}{c}\text { Marginal } \\
\text { \% Change }\end{array}$ & $\begin{array}{c}\text { Opinion } \\
\text { \% Support }\end{array}$ \\
\hline Mar-08 & $\mathbf{3 9}$ & $\mathbf{4 , 0 1 5}$ & $\mathbf{3 4}$ & $\mathbf{3 4}$ \\
Apr-08 & 52 & 4,067 & 33 & 35 \\
May-08 & 19 & 4,086 & -63 & 33 \\
Jun-08 & 29 & 4,115 & 53 & 33 \\
Jul-08 & 13 & 4,128 & -55 & 36 \\
Aug-08 & 23 & 4,151 & 77 & 35 \\
Sep-08 & 25 & 4,176 & 9 & 40 \\
Oct-08 & 14 & 4,190 & -44 & 37 \\
Nov-08 & 17 & 4,207 & 21 & 36 \\
Dec-08 & 14 & 4,221 & -18 & 35 \\
Bold indicates months when numerical battle death milestones are reached. \\
\hline
\end{tabular}

rise in casualties. This drop of approximately 20 percent, which equates to the growth of support in the months just before the war's rally effect, took place over two stages. The first drop occurred in the first four months after the end of "major combat operations," as support fell from approximately 70 percent to 60 percent. The second occurred in the subsequent eight months, when support declined another 10 percent, reaching 49 percent by May 2004. This trend appeared to follow the initial decline in support that Mueller observed during the Vietnam War with early casualties.

Next, while support continued to decline, it happened only very gradually after the first year, reaching the mid-30s by the summer of 2007, when Iraq appeared to be in the middle of a civil war and American casualties grew rapidly with a troop surge. From this point, however, support remained relatively stable, even as marginal casualties declined and the worst of the violence subsided by 2008. This, to some degree, was in line with the second part of Mueller's argument as support held in the 35 to 40 percent range with hardened supporters remaining committed in spite of continuing casualties.

Since the number of American casualties in Iraq never reached the volumes seen during the Vietnam War, it is unlikely that hardened supporters would stop supporting the war, as they did eventually in Vietnam. Nonetheless, a number of milestones $(500,1,000,2,000,3,000$, and 4,000 casualty marks) are identified in Figure 1 and Table 1 to visually assess if any noticeable decline in support was present in the months after these milestones were reached. These milestones are also highlighted in bold in Table 1. 
When the milestones are reached, there does not appear to be any discernable pattern of decline in public opinion in subsequent months. In January 2004 and March 2008, when deaths reached 500 and 4,000, respectively, public support rose slightly the following month. In September 2004, October 2005 and December 2006 when deaths reach 1,000, 2,000 and 3,000 , respectively, support declined slightly the following month. Thus, there does not appear to be much support for Hypothesis 3, as these milestones do not appear to have any discernable pattern of impact on public opinion based purely on a visual inspection.

The next visual inspection relates to Hypothesis 2a, which deals with the impact of marginal casualties, both positive and negative, on public support for the war. In this assessment, incremental casualty changes of $> \pm 50$ percent versus the previous month are identified and the support level of the following month is reviewed to determine if such shifts in casualties lead to changes in opinion in the expected direction. In total, 18 months out of the entire timeline recorded monthly shifts in casualties $> \pm 50$ percent (14 increases, 4 decreases). However, only half of the shifts in casualties lead to changes in opinion in the expected direction the following month. As such, the visual inspection of this possible relationship also shows no obvious trend. The findings from this inspection are outlined in Table 2.

In summary, while a visual examination of the public opinion time series suggests some notable reactions to wartime casualties, there is no clear effect for larger-than-average shifts in monthly casualties or body count milestones. Perhaps most notably, the relationship between casualties and support for the Iraq War over time seems to share many commonalities with the pattern Mueller identified in the Vietnam War, as the public was more sensitive to casualties earlier in the conflict than during later stages. The next section will test the hypotheses laid out in section 2 about the drivers of public support through a multivariate analysis.

\section{A Multivariate Analysis of Casualties and Public Opinion}

\section{Creating a Model}

In section 2 we presented some simple testable hypotheses relating to the body bag effect, and in section 3 we made observations based on a visual inspection of the monthly time series of casualties and support for the Iraq War. It appears from our analysis so far that large marginal casualties are not of primary importance in driving public support for the war. Moreover, the achievement of casualty milestones does not appear to make much of a difference. However, we believe a full inspection of the relationship between casualties and support for the war necessitates the use of a statistical approach. 
Table 2. Significant Marginal Casualty Changes and Support from the Iraq War, 2003-08

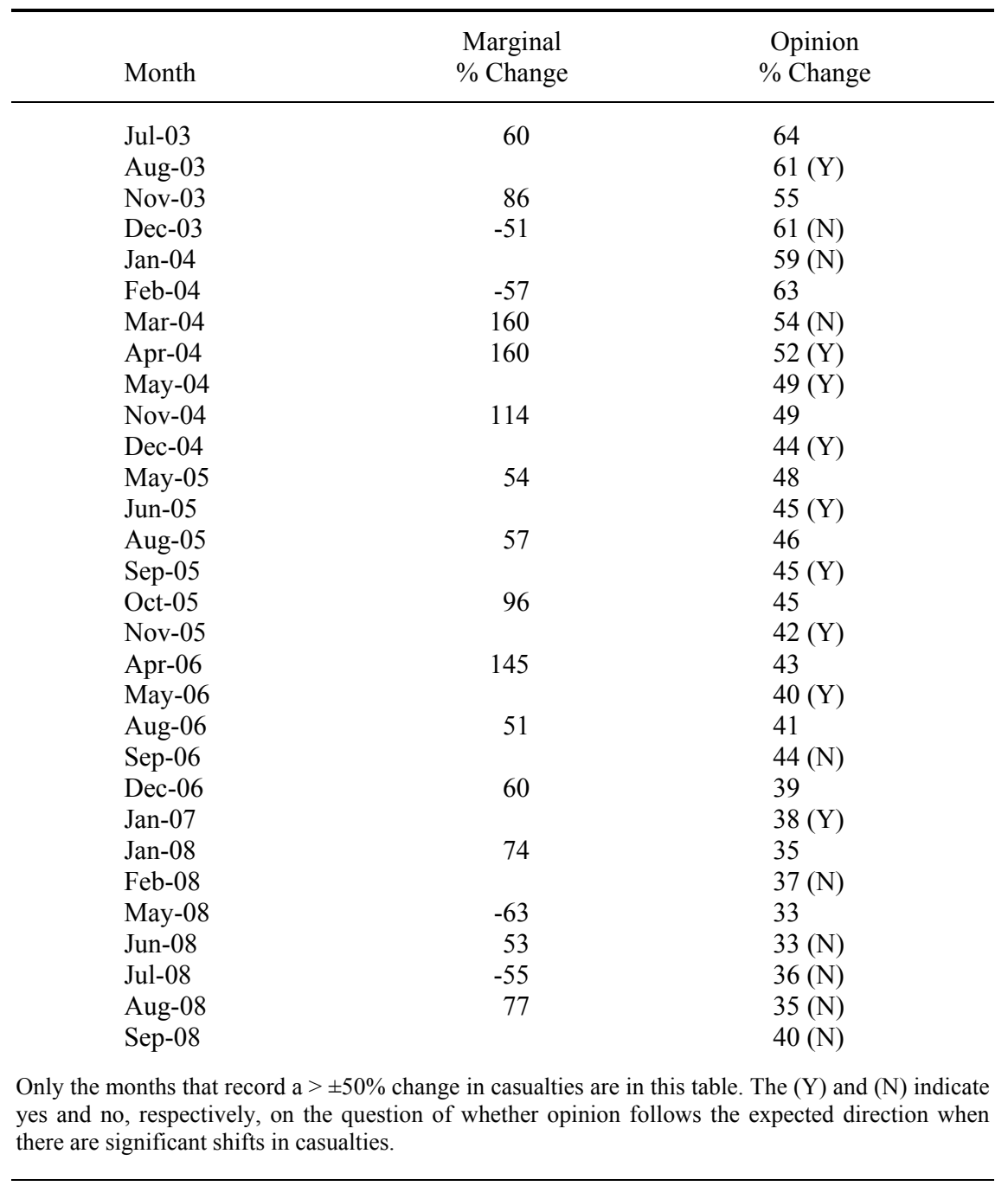

In this section, we use multivariate analysis to further test for the validity of each of the hypotheses. Ideally, multivariate models can test not only for whether an individual factor has an effect on a dependent variable in isolation, but also which proposition among many possess the greatest explanatory power. Although Ray (2002) warns against simply tossing several 
variables into the same linear model without theoretical explanations for doing so, it is common methodological practice to make several hypotheses "compete" against each other, assuming that one has theoretically valid reasons for including each variable.

In order to test Hypothesis 1, we create a variable that represents the cumulative death count up to and including a given month. This death count is hypothesized to be related to overall war weariness, and one would expect support for the war to decline as totals go up. In order to avoid problems with heteroskedasticity in our model, we use the log of cumulative casualties.

We also create two measures for recent or marginal casualties. Following from Hypothesis 2, the first is the percentage change from the previous month. This measure captures any shifts in support for the war based on the most recent casualty information. In order to capture Hypothesis 2a, we create dummy variables that capture monthly fluctuations in the death toll of greater or less than 50 percent. The idea is that public opinion may be sensitive to radical upward or downward shifts in the death count. We hypothesize here that sharp upward shifts in the monthly death count will increase public support for the war in the subsequent month, while sharp downward shifts will lead to a decrease in support.

Next, following Hypothesis 3 above, we create a dummy variable to capture each major body bag milestone. The variable is coded " 1 " for the month after the body counts reach 500, 1,000, 1,500, 2,000, 2,500, and 3,000 and 4,000; otherwise it is coded as " 0 ." If the public takes milestones into its assessments of how the war is going, then the effect of this variable will be positive and statistically significant.

To account for the effect of the duration of the war, as outlined in Hypothesis 4, we create a variable called wardays that represents the total number of days that have passed since the beginning of the Iraq War.

In order to test Hypothesis 5, the mixed cumulative-marginal casualty hypothesis of Gartner and Segura (1998), we create two competing models. In the first model, the "intuitive" model, it is expected that marginal casualties lead to lower levels of support for the war during periods of rising casualties, while greater cumulative casualties drive support down in times of declining casualties. The second model, the "counterintuitive" model, suggests the opposite of what Gartner and Segura hypothesize. Marginal casualties matter during times of declining casualties, while cumulative casualties are salient during times of rising casualties.

Following Gartner and Segura, for the "intuitive" model we examine the effect of the marginal casualty variable only during months that occur during times of rising casualties, coding the cumulative casualty variable as zero. Likewise, during times of declining casualties, we code the marginal 
casualty variable as zero, and examine only the effect of cumulative casualties.

Conversely, for the "counterintuitive" model, during months that occur during periods of rising casualties we use only the cumulative casualty variable, coding the marginal casualty variable as zero. Likewise, during periods of falling casualties, we examine only the effect of marginal casualties, coding the cumulative casualty variable as zero.

Times of rising casualties are coded as periods in which casualties during the previous 120 days were higher than they were during the 120 days prior to that. Likewise, times of declining casualties are defined as periods in which casualties during the previous 120 days were lower than during the 120-day period prior to that.

If Gartner and Segura are correct, we would expect that the marginal and cumulative casualty numbers will be statistically significant in the "intuitive" model, but that they will not achieve significance in the "counterintuitive" model. If they are not correct we will not notice a statistical difference between the coefficients for marginal and cumulative casualties in the two models.

Finally, we test Hypothesis 6, the proposition that neither cumulative nor marginal casualties matter. If the coefficients for both marginal and cumulative casualties are not statistically significant, this will lend support to the idea that body bag counts do not explain public support for the war, and we thus assume domestic political factors offer the most satisfactory answers.

\section{Methodological Approach for Predicting Support for the War}

As mentioned, this section attempts to assess the role of body bag factors in predicting public opinion support for the war. Data are taken from the first seventy-two months of the war. The dependent variable is the percentage of the public that supports the war effort. The independent variables are the cumulative death count, the monthly death count, a battle death milestone variable, and a dummy variable that captures whether or not deaths increased or decreased by 50 percent in a given month.

The method for answering this question is a multivariate regression using time series analysis. We create a model that predicts the level of support for the war in a given month. In other words, we observe whether these factors actually have an effect on public support that is significantly different than what we would expect to see by random chance.

Our model is specified as: 


\section{Public Support $=$ Cumulative Casualties + Marginal Casualties + Increase $50+$ Decrease $50+$ Milestone + Wardays}

where public support is the dependent variable, and all of the other factors on the right-hand side of the equation are explanatory variables. Table 3 contains a list of all variables to be tested in the model, and includes a description of what values a variable can take in a given month. It also discusses which effect we hypothesize might occur in conjunction with an increase in the value of a given variable (for instance, we might see higher levels of death in a month associated with lower levels of support for the war).

We test our model using a Box-Jenkins regression. Because we are using time series data, using a standard Ordinary Least Squares regression leaves open the possibility that our model would violate the assumption that the mean of each independent variable does not vary over time (i.e., that each mean is stationary). Because diagnostic tests show that one of our independent variables (cumulative casualties) has a non-stationary mean, using OLS regression on that variable would violate the assumption of independence between the dependent and independent variables. The result could be a spurious regression: public approval for the war and cumulative casualties might be correlated when a third factor, such as time, is really driving their relationship. Moreover, standard fixes for first-order serial correlation (the Prais-Winston and Cochrane-Orcutt procedures), do not eliminate the problem of non-stationarity in the data. The Box Jenkins approach allows one to remove the time dependence in the model so that its residuals are a 'white noise' process (i.e., there is no serial correlation in the error term).

The basic model for a Box Jenkins model is $D(d) Y_{t}=a_{0}+A R(P)+$ $M A(q)+E_{v}$, where $Y_{t}$ is a stationary time series, $a_{0}$ is the constant, $A R(p)$ indicates the number of autogressive structures, $D(d)$ is the number of times that $Y_{t}$ must be differenced for the series to become stationary, and $E_{v}$ is the error term. The statistical processes underlying the series are modeled using the ARIMA (Enders 2004) auto-regression integrated moving average) identification and estimation procedures described in Enders (2004). We find that the only Box-Jenkins model that creates white noise residuals is an ARIMA $(0,1,1)$ specification, meaning that the best specified model is one that uses zero autoregressive structures, one differencing parameter, and one moving average parameter. Diagnostic tests of the residuals of this ARIMA $(0,1,1)$ model (the Augmented Dickey-Fuller test, the Ljung-Box $q$-statistic and the Phillips-Perron test) reveal no serious threat of non-stationarity, and an inspection of the cross-correlations of the error term at different time lags reveals no signs of significant autocorrelation. Therefore, we can say that (unlike OLS), our models do not violate the assumption of independence between the independent and dependent variables (Enders 2004). 
Table 3. Summary of Independent Variables

\begin{tabular}{lll}
\hline Variable & Description & Hypothesized Effect \\
\hline $\begin{array}{l}\text { Cumulative } \\
\text { Casualties }\end{array}$ & $\begin{array}{l}\text { Sum of All Casualties } \\
\text { Since Beginning of War }\end{array}$ & Decrease In Support \\
$\begin{array}{l}\text { Monthly } \\
\text { Casualties }\end{array}$ & $\begin{array}{l}\text { Number of Casualties in a } \\
\text { Given Month }\end{array}$ & Decrease in Support \\
$50 \%$ Increase & $\begin{array}{l}\text { Coded as '1' When Increase } \\
\text { of }>50 \% \text { in Rate of Casualties }\end{array}$ & Decrease in Support \\
& $\begin{array}{l}\text { From the Previous Month; } \\
\text { Otherwise Coded as '0' }\end{array}$ & \\
& $\begin{array}{l}\text { Coded as '1' When Decrease } \\
\text { of }>50 \% \text { in Rate of Casualties }\end{array}$ & Increase in Support \\
From the Previous Month; & \\
& Otherwise Coded as '0' & \\
Month in Which Death Toll Hits & \\
Milestone & 500, 1,000, 2,000, 3,000 and 4,000 & Decrease in Support \\
& Number of Days Since Onset of War & Decrease in Support \\
\hline
\end{tabular}

\section{The Evidence}

Do we find evidence for the body bag effect? And if so, which of the hypotheses best predict public support for the war?

The evidence from Table 4, which includes all models, makes a strong case for Hypothesis 1. Analysis of time series data from the first six years of the war suggests that cumulative casualties are a key force behind support for the war: the higher the number of cumulative deaths, the lower the level of support for the war. While the impact of one casualty may not be of great importance overall, the result of several thousand casualties may be telling. Model 1, which contains only the parameter for cumulative casualties, predicts the degree of support for the Iraq War quite well. In fact, Model 1 performs as well or almost as well as Model 3, which contains all of the variables listed in Table 3. According to two "goodness of fit" measures, the AIC (Akaike Information Criterion) and the BIC (Bayesian Information Criterion), the fit of Model 1 to the data is the best of any of the models. Model 2 (which contains both cumulative and marginal casualties) and Model 3 (which contains all of the variables listed in Table 2) do not perform noticeably better in terms of goodness of fit. Moreover, the effect of the log of cumulative casualties is statistically significant in all of the 
Table 4. Tests of Hypotheses

\begin{tabular}{|c|c|c|c|c|c|}
\hline Variable & Model 1 & Model 2 & Model 3 & $\begin{array}{c}\text { Model } 4 \\
\text { (Intuitive) }\end{array}$ & $\begin{array}{c}\text { Model } 5 \\
\text { (Counter) }\end{array}$ \\
\hline $\begin{array}{l}\text { Cumulative } \\
\text { Casualties }\end{array}$ & $\begin{array}{c}-17.20 * * * \\
(3.69)\end{array}$ & $\begin{array}{c}-16.30 * * * \\
(4.57)\end{array}$ & $\begin{array}{c}-15.26^{*} \\
(7.36)\end{array}$ & & \\
\hline $\begin{array}{l}\text { Marginal } \\
\text { Casualties }\end{array}$ & & $\begin{array}{l}-.13 \\
(.46)\end{array}$ & $\begin{array}{l}-.003 \\
(.012)\end{array}$ & & \\
\hline $50 \%$ Increase & & & $\begin{array}{l}-.822 \\
(1.24)\end{array}$ & $\begin{array}{l}-1.22 \\
(.81)\end{array}$ & $\begin{array}{l}-1.18 \\
(.85)\end{array}$ \\
\hline $50 \%$ Decrease & & & $\begin{array}{l}-2.92^{*} \\
(1.29)\end{array}$ & $\begin{array}{l}-2.98^{* *} \\
(1.14)\end{array}$ & $\begin{array}{l}-2.75^{*} \\
(1.20)\end{array}$ \\
\hline Milestone & & & $\begin{array}{l}-.55 \\
(.80) \\
\end{array}$ & $\begin{array}{l}-.71 \\
(.91) \\
\end{array}$ & $\begin{array}{c}-.20 \\
(1.03) \\
\end{array}$ \\
\hline Wardays & & & $\begin{array}{c}.08 \\
(1.04)\end{array}$ & $\begin{array}{l}-.005 \\
(1.02)\end{array}$ & $\begin{array}{c}.06 \\
(1.16)\end{array}$ \\
\hline CAS120UP & & & & $\begin{array}{l}-.03^{*} \\
(.01) \\
\end{array}$ & \\
\hline CAS120DOWN & & & & & $\begin{array}{c}.003 \\
(.011)\end{array}$ \\
\hline Log CASDOWN & & & & $\begin{array}{l}-2.65^{*} \\
(1.08) \\
\end{array}$ & \\
\hline Log CASUP & & & & & $\begin{array}{l}.122 \\
(.90) \\
\end{array}$ \\
\hline Prob $>F$ & 0.000 & 0.000 & 0.000 & 0.000 & 0.000 \\
\hline $\mathrm{N}$ & 72 & 71 & 71 & 65 & 65 \\
\hline AIC & 347.83 & 345.99 & 345.79 & 317.62 & 323.99 \\
\hline $\mathrm{BIC}$ & 356.94 & 357.31 & 366.15 & 337.19 & 343.56 \\
\hline
\end{tabular}

Standard errors in parentheses: $* \mathrm{p}<.05 ; * * \mathrm{p}<.01 ; * * * \mathrm{p}<.001$, one-tailed tests.

Values reported are regression coefficients. For each model, the values of the augmented DickeyFuller test statistic, the Ljung-Box $q$-statistic, and the Phillips-Perron statistic are available from the authors.

models. It is therefore clear that the factor that has the greatest of the explanatory power in terms of predicting approval is the log of cumulative casualties.

By comparison, we do not find much support for Hypothesis 2. While higher levels of marginal monthly casualties are associated with lower levels of support for the war in the following month in Models 2 and 3, the coefficient is not statistically significant. Likewise, the fit of Model 2 (which includes both marginal and cumulative casualties) to the data is slightly worse 
than the fit of Model 1 according to the AIC measure, and only slightly better according to the BIC measure. When we test the effect of marginal casualties in a bivariate model to identify its independent effect on the dependent variable (regression results not shown), the coefficient for marginal casualties is not statistically significant. Thus, it is apparent that the log of cumulative casualties plays a more important role than marginal casualties in predicting levels of support for the Iraq War.

But perhaps the public only responds to very large short-term shifts in casualty rates, while it fails to react to small ones. Hypothesis $2 \mathrm{a}$ is designed to account for this possibility by suggesting that only sizeable monthly casualty rate changes (either 50 percent higher or lower) have an impact on support for the war. An examination of Model 3 reveals that the effect of the dummy variable that denotes months where casualty rates increased by 50 percent is not statistically significant. This suggests that the public is not likely to drop its support for the war in response to sharp increases in casualties.

In contrast, the coefficient for large monthly decreases in casualties is negatively signed and statistically significant, meaning that months following 50 percent of greater monthly declines in casualties are associated with lower approval for the war. This is an unexpected finding, as there does not appear to be any intuitive reason why mass publics would be less likely to support a conflict immediately following a sizeable downward shift in casualties. We think that the best single explanation for this statistical relationship can be found at a single time point in the data set. In February of 2004 , the marginal casualty change was -57 percent, but the approval rate for the war fell from 63 percent in February to 54 percent in March. This drop in approval, although it followed a month during which casualties fell sharply, constitutes the highest monthly opinion shift of the entire 72-month period in either direction. Thus, the month of March 2004 alone can entirely explain the statistically significant relationship in the model, as its exclusion from the data set makes the relationship lose its statistical significance.

Why did this curious drop in support occur? We believe that while marginal casualties dropped sharply in February 2004, it was during this time that the Iraqi insurgency began to strengthen dramatically, shattering the illusion that the capture of Saddam Hussein in December 2003 would effectively end the war. Due to this loss of public confidence from the growing insurgency, even a sharp drop in marginal casualties did very little to assuage public fears about the war. Another possible explanation is that while deaths were sharply down in February, they rapidly increased again in March. Thus, some polling in March may have occurred after battle deaths began to take a sharp turn in an upward direction. 
March 2004 aside, we do not find much evidence for Hypothesis 2a. Thus, there is little reason to believe that sharp increases or decreases in monthly casualties play an important role in determining support levels for the Iraq War.

Hypothesis 3 suggests that in the month after the cumulative death toll reaches an important psychological milestone (i.e., 500, 1,000, 2,000, 3,000, and 4,000 deaths), levels of support will be lower than the previous month. However, we do not find that the coefficient for the milestones dummy variable is statistically significant. Nor does the inclusion of the milestone variable noticeably improve overall model fit. However, when one analyzes the 1,000 -casualty threshold in isolation from the others, its effect is statistically significant. This would appear to make sense, as the symbolic 1,000 number is quite possibly the biggest psychological barrier amongst the options reviewed.

The generally weak performances of Hypotheses 2, 2a, and 3 suggest that one should not place much weight in the claim that short-term changes in casualties drive the level of support for the Iraq War.

According to Hypothesis 4, support for the war is likely to erode over time as the war progresses. An examination of Model 3 shows that the findings do not support the idea that the duration of the conflict is associated with lower levels of support. The coefficient for the wardays variable is in the expected direction, but it is not statistically significant.

Next, we examine Hypothesis 5, relating to Gartner and Segura's (1998) findings that marginal casualties matter more for public support during periods of rising casualties, while cumulative casualties matter more during times of falling casualties. We find some evidence to suggest that similar trends were at play during the first six years of the Iraq War. Models 4 and 5 are replications of the two competing models that Gartner and Segura use to test whether the relative salience of cumulative and marginal casualties depends upon whether wartime casualties have been rising or declining over the past several months of the conflict.

Our Model 4 is similar to their first "intuitive" model, which examines marginal casualties only during times when the four-month trend is upward. In phases when casualties are in a downward trend, it treats marginal casualties as zero. In this way, Model 4 captures only the effect of marginal casualties during times of escalating battle deaths. Likewise, it captures the number of cumulative casualties only in periods when the previous four months have recorded decreasing casualties. The "counterintuitive" model (which we recreate in Model 5) does just the opposite - it captures the effect of marginal casualties only when the four-month casualty trend points downward and the effect of cumulative casualties only when the trend is upward. If Gartner and Segura's hypothesis is true, then both estimates in the intuitive 
model would be statistically significant, while neither of the estimates in the counterintuitive model would be.

We find support for Gartner and Segura's hypothesis. The two "intuitive" parameters in Model 4 (marginal casualties during times of rising body bag counts and cumulative casualties during times of declining body bag counts) are both statistically significant, as an increase in both is associated with lower levels of support. At the same time, the coefficients for the two "counterintuitive" variables are not statistically significant. The fact that the same relationship emerged for three different conflicts would appear to lend support the possibility that the popularity of wars occurs in the context of how well the war seems to be going at the time. However, we must view the apparently successful replication of Gartner and Segura's analysis with caution. The goodness of fit measures (the AIC and BIC) for the intuitive measure are actually slightly worse than they are for the counterintuitive model. And the goodness of fit of Model 4 is not as good as that of Model 3, which includes all of the variables we propose to test in Table 3. So we cannot say that Gartner and Segura's model does a better job of predicting support for the war. The inconclusive nature of their results suggests that more work is necessary before we can confirm or reject their hypothesis.

As for Hypothesis 6, the null hypothesis, our statistical results demonstrate that there was a clear decline in support for the war as cumulative casualties mounted. Thus, the evidence from our model suggests that we should reject the null hypothesis that wartime casualty figures do not affect public support for the war. If partisan cues or other domestic factors are in operation, then they exist in the context of a mounting body bag count. However, it is impossible to confirm this without individual level data to understand whether the public is responding to deaths directly or indirectly through other factors such as elite cues.

In short, we can say that the best predictor of support for the war in a given month during the war is the number of cumulative casualties. We can see this in the "goodness of fit" model statistics in Table 4. The fact that Model 1 fits the data as well or better than any model suggests that most of the variation in support for the Iraq War can be explained by long-term casualty figures, not short-term variations in body bag counts, the achievement of significant death count milestones, or the duration of time itself.

\section{Conclusion}

Was the body bag effect a factor in the Iraq War? An analysis of the relationship between the monthly time series of support for the war over the first six years and a number of purported covariates suggests that, more than anything else, it is the overall number of deaths that influence public support 
for the war. Cumulative casualties appear to have a greater effect on support than either monthly changes in casualties, the attainment of significant war death milestones, or the passage of time itself. While our analyses do not completely refute the idea that the relative importance of marginal and cumulative casualties may vary upon whether deaths are trending upward or downward, it is clear that the best predictor of monthly variations in support is the log of cumulative casualties.

We conclude by suggesting that because the public is sensitive to cumulative battle deaths, it appears to be collectively rational and capable of developing attitudes about the conflict from information about the war. Such a finding falls in line with those of other researchers who argue that the public assesses their government's involvement in wars in a rational fashion. However, in the case of the Iraq War, it appears that the public was not particularly focused on monthly fluctuations in the number of body bags. We must consider the possibility that the lower and more stable levels of monthly casualties did not evoke the same type of reactions from the public as was the case during the Korean and Vietnam Wars.

It is important to note that our analysis has been based on the examination of aggregate-level data. Berinsky (2007) argues that such wartime information does have a role in shaping public opinion. However, his individuallevel studies argue that elite cues play a powerful role in the filtering of this information to the public. Nonetheless, the evidence here suggests that individuals do appear to be somewhat rational about wartime information, at least in the long term. Furthermore, events after 2008 in the Afghanistan War, which recorded a decline in public support even as both Republican and Democrat political leaders officially supported the war, provides additional weight to our findings and suggests that the public can be rational and even independent of elite cues.

Future research will need to devise mechanisms to test other versions of the body bag effect. It will be useful to understand, for example, the role that a decline in war support has on the policy process. In the case of the Iraq War, strategy changed a number of times in response to the war's perceived lack of success. It will be important to find ways to identify and assess the impact of those policy changes over the timeline of the study, and to use individual-level data to determine whether there is a link between such policy shifts and changes in the level of public support.

\section{REFERENCES}

Baum, Matthew A., and Tim J. Groeling. 2010. War Stories: The Causes and Consequences of Public Views of War. Princeton, NJ: Princeton University Press. 
Berinsky, Adam. 2007. Assuming the Costs of War: Events, Elites, and American Support for Military Conflict. Journal of Politics 69:975-997.

Berinsky, Adam. 2009. In Time of War: Understanding Public Opinion, From World War II to Iraq. Chicago: University of Chicago Press.

CNN/USA Today Poll. 2007.

Coker, Christopher. 2001. Humane Warfare. London: Routledge.

Daalder, Ivo, and Michael E. O'Hanlon. 2000. Winning Ugly: NATO's War to Save Kosovo. Washington, DC: Brookings Institution Press.

Enders, Walter. 2004. Applied Econometric Time Series, 2nd ed. Hoboken, NJ: John Wiley \& Sons.

Entman, Robert. 2004. Framing News, Public Opinion, and U.S. Foreign Policy. Chicago: University of Chicago Press.

Entman, Robert. 2000. Declarations of Independence: The Growth of Media Power after the Cold War. In Decisionmaking in a Glass House: Mass Media, Public Opinion, and American and European Foreign Policy in the 21st Century, eds. B. Nacos, Robert Shapiro, and Pierangelo Isernia. Lanahan, MD: Rowman \& Littlefield Publishers, Inc.

Freedman, Lawrence. 2000. Victims and Victors: Reflections on the Kosovo War. Review of International Studies 26:335-358.

Gartner, Scott Sigmund, And Gary M. Segura. 1998. War, Casualties, and Public Opinion. Journal of Conflict Resolution 42:278-300.

Gelpi, Christopher. 2010. Performing on Cue? The Formation of Public Opinion toward War. Journal of Conflict Resolution 54:88-116.

Gelpi, Christopher, Peter Feaver, and Jason Reifler. 2005. Success Matters: Casualty Sensitivity and the War in Iraq. International Security 30:7-46.

Hallin, Daniel. 1989. The Uncensored War. Berkeley: University of California Press.

Hetherington, Marc J., and Michael Nelson. 2003. Anatomy of a Rally Effect: George W. Bush and the War on Terrorism. PS: Political Science and Politics 36:37-42.

Holsti, Ole R. 2002. Public Opinion and Foreign Policy Analysis: Where We Were, Are, and Should Strive to Be. In Millennial Reflections on International Studies, eds. Michael Brecher and Frank P. Harvey. Ann Arbor: University of Michigan Press.

Jentleson, Bruce. 1992. The Pretty Prudent Public: Post Post-Vietnam American Opinion on the Use of Military Force. International Studies Quarterly 36:49-73.

Jentleson, Bruce. 1998. Still Pretty Prudent: Post-Cold War American Public Opinion on the Use of Military Force. Journal of Conflict Resolution 42:395-417.

Livingston, Steven. 2000. Media Coverage and the War: An Empirical Assessment. Pp. 360-384 in Kosovo and the Challenge of Humanitarian Intervention: Selective Indignation, Collective Action, and International Citizenship, eds. Albrecht Schnabel and Ramesh Thakur. Tokyo, New York, Paris: United Nations University Press.

Mueller, John. 1973. War, Presidents and Public Opinion. New York: John Wiley.

Pew Research Center for the People and the Press. 1998. Public Appetite for Government Misjudged: Washington Leaders Wary of Public Opinion.

Ray, James Lee. 2002. Explaining Interstate Conflict and War: What Should Be Controlled For? Peace Science Society Meeting, Tucson, AZ, Nov. 1-3.

Secretary, White House Office of the Press. 1999. Address by the President to the Nation, March 24.

von Clausewitz, Carl. 1993. On War, eds. M. Howard and P. Paret. London: Everyman.

Zaller, John R. 1992. The Nature and Origins of Mass Opinion. Cambridge, UK: Cambridge University Press. 
Zaller, John R., and Dennis Chiu. 2000. Government's Little Helper: U.S. Press Coverage of Foreign Policy Crises, 1948-1999. In Decisionmaking in a Glass House: Mass Media, Public Opinion, and American and European Public Policy in the 21st Century, edited by B. Nacos, R. Shapiro, and P. Isernia. Lanahan, MD: Rowman \& Littlefield Publishers, Inc. 